\title{
Seed testa sculpture of species of Allium L. (Amaryllidaceae) and its taxonomic implications
}

\author{
Sh. Baasanmunkh ${ }^{1,5 *}$, H. J. Choi ${ }^{1,6}$, B. Oyuntsetseg ${ }^{2,7}$, N. Friesen ${ }^{3,4,8 *}$ \\ ${ }^{1}$ Department of Biology and Chemistry, Changwon National University, Uichang-gu, 35, Changwon, 51140, South Korea \\ ${ }^{2}$ Department of Biology, School of Arts and Science, National University of Mongolia, Ikh Surguuliin \\ Gudamj, 1, Ulaanbaatar, 14201, Mongolia \\ ${ }^{3}$ Botanical Garden of the University of Osnabrueck, Albrechtstrasse, 29, Osnabrueck 49076, Germany \\ ${ }^{4}$ I. M. Sechenov First Moscow State Medical University Ministry of Health of the Russian Federation, Department of \\ Pharmaceutical and Natural Sciences, Izmailovsky Boulevard, 8, Moscow, 105043, Russian Federation \\ ${ }^{5}$ E-mail: baasanmunkh.sh@gmail.com; ORCID iD: https://orcid.org/0000-0003-4224-9376
${ }^{6}$ E-mail: hjchoi1975@changwon.ac.kr; ORCID iD: https://orcid.org/0000-0001-6315-0071
${ }^{7}$ E-mail: oyunaa@num.edu.mn; ORCID iD: https://orcid.org/0000-0003-3772-3301
${ }^{8}$ E-mail: nfriesen@uni-osnabrueck.de; ORCID iD: https://orcid.org/0000-0003-3547-3257 \\ *Corresponding authors
}

Keywords: herbarium collection, section, seed macro-morphology, subgenus, taxonomic signification.

Summary. We investigated the seed testa sculpture of twenty-four species belonging to thirteen sections and five subgenera of Allium from the herbarium materials or collected from plants in living collections. Seed testa sculpture of 21 species were described for the first time in this study. According to our results, the straight anticlinal wall and one large verruca or dense granules periclinal wall were found among the species in subgenus Amerallium, Cepa, Polyprason and Reticulatobulbosa. Only A. ochroleucum (sect. Daghestanica, subg. Polyprason) has U-type undulation anticlinal wall, which is similar to species of subg. Allium. The U- to Omega-type undulation anticlinal walls and several big verrucae with marginal verrucae periclinal wall were found in subg. Allium. Our results suggest that seed testa sculpture is important character of species and sections level of the genus Allium.

\section{Скульптура поверхности семян видов рода Allium (Amaryllidaceae) и её таксономическое значение}

\author{
Ш. Баасанмунх ${ }^{1}$, Х. Ч. Чой${ }^{1}$, Б. Оюунцэцэг ${ }^{2}$ Н. Фризен ${ }^{3,4}$ \\ ${ }^{1}$ Чханвонский Национальный университет, Учанг-гу, 35, г. Чханвон, 51140, Южная Корея \\ ${ }^{2}$ Монгольский государственный университет, Университетская улииа, 1, г. Улан-Батор, 14201, Монголия \\ ${ }^{3}$ Ботанический сад Оснабрюкского университета, Альбрехтитрассе, 29, г. Оснабрюк, 490776, Германия \\ ${ }^{4}$ Первый Московский государственный медичинский университет им. И. М. Сеченова, Измайловский \\ бульвар, 8, г. Москва, 105043, Российская Федерачия
}

Ключевые слова: гербарная коллекция, секция, скульптура поверхности семян, таксономическое значение. 


\begin{abstract}
Аннотация. Изучена скульптура поверхности семян 24 видов, относящихся к 13 секциям и пяти подродам рода Allium. Семена взяты с гербарных образцов или с растений из живых коллекций. Нами впервые описана скульптура поверхности семенной оболочки у 21 вида. Согласно полученным результатам, виды подродов Amerallium, Cepa, Polyprason и Reticulatobulbosa имеют прямую антиклинальную стенку и один крупный бугорок или периклинальную стенку с плотными гранулами на поверхности. Только у A. ochroleucum (sect. Daghestanica, subg. Polyprason) выявлена волнистая антиклинальная стенка U-типа, как у видов подрода Allium. Волнистые антиклинальные стенки от U- до Omega-типа и несколько больших бугорков с периклинальной стенкой были выявлены в подроде Allium. Наши результаты показывают, что скульптура поверхности семян является важным таксономическим признаком на уровне видов и секций рода Allium.
\end{abstract}

\section{Introduction}

Seed morphology and seed testa studies have been suggested to be taxonomically useful for species and section rank detection in the genus Allium. Seed testa sculpture of anticlinal wall with S-, U-, Omega-, and straight type undulation and one central verruca with marginal verrucae or densely granulose periclinal wall are important characters to sections and subgenera level (Baasanmunkh et al., 2020). For instance, straight anticlinal walls were dominated in subg. Cepa, Reticulatobulbosa and Polyprason and the periclinal walls were distinguished by central big verruca and dense granules. The U-, Omega- and S-type undulation anticlinal walls and convex periclinal walls with several large verrucae or marginal verrucae were dominated in subg. Allium and Melanocrommyum (Celep et al., 2012; Lin, Tan, 2017; Veiskarami et al., 2018; Baasanmunkh et al., 2020). Additionally, several new taxa of Allium have been recognized based on their morphology including seed macroand micro-morphological characteristics and phylogenetic studies (Deniz et al., 2015; Duman et al., 2017).

The genus Allium L., one of the most diverse and the largest genus of petaloid monocots (Friesen et al., 2006; Li et al., 2010), comprises more than 1000 species (Govaerts et al., 2005-2021). This genus is naturally distributed in the Northern Hemisphere (Friesen et al., 2006) and its main diversity is in the mountainous areas of southwestern and central Asia (Fritsch, Friesen, 2002; Friesen et al., 2006).

To date, seed morphology and seed testa sculpture of 460 taxa have been studied from different countries (Baasanmunkh et al., 2020). In particular, most of species were investigated from the Turkey, Iran and Central Asian countries (Celep et al., 2012; Lin, Tan, 2017; Veiskarami et al., 2018; Baasanmunkh et al., 2020). However, seed morphological studies of many species and sections of Allium is remaining. In particular, Friesen et al. (2006) described several new sections such as Daghestanica (Tscholok.)
N. Friesen (subg. Polyprason), Nigrimontana N. Friesen and Sikkimensia (Traub) N. Friesen (subg. Reticulatobulbosa) based on morphological and molecular phylogenetic analysis.

The article provides descriptions of the surface sculpture of 24 species of Allium made by the last author 15 years ago. The descriptions of testa sculpture of most of them have not yet been published in previous works. Since 24 species represent 13 sections and 5 subgenera in the genus Allium (three samples are type species of sections Daghestanica: Nigrimontana and Sikkimensia), they complement the spectrum of species whose testa sculpture has been published so far and contribute the understanding of the evolutionary and taxonomic significance of seed surface sculpture for the classification of the genus.

\section{Material and Methods}

Specimens information with species/ classification and origin are presented in Table 1.

No special pre-treatments were applied for the preparation of scanning electron microscopy (SEM). Seeds were immersed in absolute ethanol and sputtered with a gold coating in a Sputter Coater: Polaron E5150, Polaron Equipment Ltd, Hertfordshire, England. In all cases, the seeds of at least five samples per accession were analysed, characterized, and photographed with a Zeiss DSM 926 (Zeiss, Oberkochen, Germany) scanning electron microscope at the Zoological Department of the Osnabrueck University.

Terminologies for the description of seed testa sculpture is according to Barthlott (1981), Celep et al. (2012) and Baasanmunkh et al. (2020).

\section{Result and Discussion}

Recently, seed testa sculpture of Allium have been quite well studied from different countries based on the herbarium and field collection materials (Celep et al., 2012; Lin, Tan, 2017; Veiskarami et 
al., 2018; Baasanmunkh et al., 2020). In this study, we investigated seed testa sculpture of 24 species in genus Allium L. based on herbarium materials and seed collected in the living Allium collections in Institute of Plant Genetics and Crop Plant Research, Gatersleben, Germany and Botanical Garden of the Osnabrueck University, Germany (GAT and OSN accessions in the table 1, respectively). Among these, seed testa sculpture of 21 species have been studied for the first time. The seed testa micrographs are sorted in alphabetical order of subgenus, section and species names (Table 2; Figs. 1, 2). Each species and sections of the subgenera are discussed and provided below.

\section{Subgenus Allium}

The subg. Allium comprises more than 380 species (Khasanov, 2018) and is placed at third evolutionary line in genus Allium (Hanelt et al., 1992; Friesen et al., 2006). The U-, S-, Omega-type undulation anticlinal wall and convex periclinal wall with one central verruca or several marginal verrucae were dominated in subg. Allium (Pastor, 1981; Kruse, 1984, 1986, 1988, 1994; Neshati, Fritsch, 2009; Choi et al., 2012; Duman et al., 2017; Lin, Tan, 2017; Veiskarami et al., 2018). To date, seed morphological of 140 taxa have been studied from different sections in subg. Allium (Baasanmunkh et al., 2020). We studied six species (A. ampeloprasum L., A. aucheri Boiss., A. cappadocicum Boiss. et Balansa, A. sphaerocephalum L., A. synnotii G. Don and A.pictistamineum O. Schwarz) belonging to two sections (Allium and Codonoprasum) in this subgenus. Seed testa sculpture of the most species was described for the first time. The testa cells were distinguished in irregularly polygonal (Fig. 1A, C, E) and elliptic polygonal (Fig. 1B, D, F). The U- type undulation anticlinal walls were found among the species except $A$. aucheri (Omega-type undulation, Fig. 1B). The convex or concave periclinal walls with one central or several big verrucae were dominated among the studied species.

Subgenus Amerallium Traub.

We described seed testa sculpture of two species A. fasciculatum Rendle (sect. Brommatorhiza) and A. stellatum Nutt. ex Ker Gawl. (sect. Lophyoprason) in this subgenus. Allium fasciculatum was investigated for the first time here. The testa cell was irregularly polygonal 3-4-edged and irregularly polygonal in $A$. fasciculatum (Fig. $1 \mathrm{G}$ ) and A. stellatum (Fig. 1H), respectively. Choi and CotaSánchez (2010) studied straight anticlinal wall and periclinal wall with minutely roughened for
A. stellatum from Canada. Our result was suggested similar result for anticlinal wall but periclinal wall somewhat differs from result of Choi and CotaSánchez (2010).

Subgenus Cepa (Mill.) Radić.

The straight, straight to arched anticlinal wall and several big verrucae with small granulate periclinal wall were dominated in this subgenus (Kruse, 1986; Bednorz et al., 2011; Baasanmunkh et al., 2020), while some species (A. cepa $\mathrm{L}$. and A. atrosanguineum Schrenk) from China (Xinjiang) had the S-type undulation anticlinal walls (Lin, Tan 2017). We investigated two species (A. taquetii H. Lév. et Vaniot and A. oliganthum) belonging to two sections (Sacculiferum and Schoenoprasum) in this subgenus, respectively. Of these, A. oliganthum Kar. et Kir. has straight anticlinal wall and flat, smooth periclinal wall (Fig. 1J) described for the first time. Choi et al. (2012) studied the straight anticlinal wall and granulate periclinal wall for A. taquetii, but our result showed the several big verrucae periclinal wall (Fig. 1I). It is might be that our $A$. taquetii sample was misidentified. The testa cell was irregularly polygonal 4-5-edged for both species (Fig. 1I, J).

\section{Subgenus Polyprason Radić.}

We investigated six species (A. daghestanicum Grossh., A. gunibicum Miscz. ex Grossh., A. ochroleucum Waldst. et Kit., A. suaveolens Jacq., A. zaprjagajevii Kassacz. and A. stracheyi Baker) belonging to three sections (Daghestanica, Falcatifolia and Oreiprason) in this subgenus. In this study seed testa of all the species was described for the first time, except A. daghestanicum. Kruse $(1984,1988)$ found straight anticlinal wall and verrucae with granulose periclinal wall for A. daghestanicum (sect. Daghestanica), which is same to our result.

\section{Subgenus Reticulatobulbosa (Kamelin) N. Friesen. \\ The straight anticlinal walls and granulose} sculptures of the periclinal walls dominated in this subgenus (Kruse, 1984, 1986, 1988, 1994; Fritsch et al., 2006; Choi et al., 2012; Lin, Tan, 2017; Baasanmunkh et al., 2020). We investigated eight species (A. oreoscordum Vved., A. trachyscordum Vved., A. henryi C. H. Wright, A. drobovii Vved., A. maackii (Maxim.) Prokh. ex Kom., A. beesianum W. W. Sm., A. forrestii Diels and A. sikkimense Baker) belonging to four sections (Campanulata, Nigrimontana, Reticulatobulbosa and Sikkimensia) 
in this subgenus. Seed testa of all the species was described for the first time here. The testa cell was irregularly polygonal with 3-5 edges among the species studied (Fig. 2E-L). All studied species have straight anticlinal walls whereas periclinal walls distinguished by many small granules in $A$ henryi (sect. Sikkimensia) (Fig. 2I), one central verruca with marginal small verrucae in $A$. oreoscordum,
A. trachyscordum (sect. Campanulata) (Fig. 2E, F) and A. maackii (sect. Reticulatobulbosa) (Fig. 2H), many or several verrucae in A. drobovii (sect. Nigrimontana) (Fig. 2G) and A. beesianum (sect. Sikkimensia) (Fig. 2J), and densely prominent granules in $A$. forrestii and A. sikkimense (sect. Sikkimensia) (Fig. 2K, L). Our findings agreed with previous results, that straight anticlinal walls
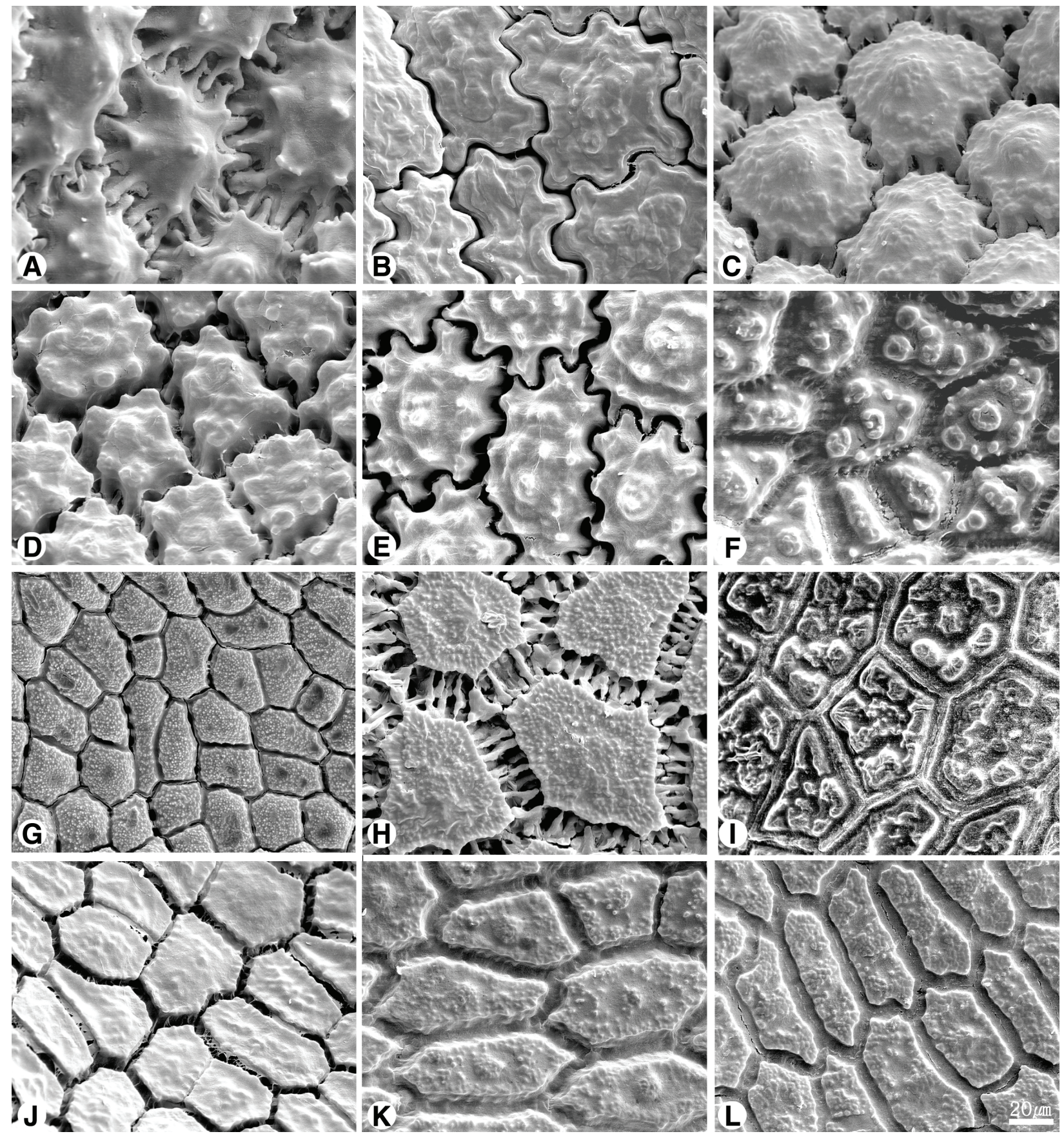

Fig. 1. Seed testa sculptures of Allium. A-F - subg. Allium: A - A. ampeloprasum; B - A. aucheri; C - A. cappadocicum; $\mathrm{D}-$ A. sphaerocephalum; E - A. synnotii (sect. Allium); F - A. pictistamineum (sect. Codonoprasum). $\mathrm{G}-\mathrm{H}-\mathrm{subg}$. Amerallium: $\mathrm{G}-$ A. fasciculatum (sect. Brommatorhiza); H - A. stellatum (subg. Amerallium, sect. Molium). I-J subg. Cepa: I - A. taquetii (sect. Sacculiferum); J - A. oliganthum (sect. Schoenoprasum). K-L - subg. Polyprason: $\mathrm{K}-$ A. daghestanicum; L - A. gunibicum (sect. Daghestanica) (Photo N. Friesen). 
dominate in the subg. Reticulatobulbosa (Lin, Tan 2017; Baasanmunkh et al., 2020). Especially, the periclinal walls of sect. Sikkimensia were clearly different from sects. Campanulata and Nigrimontana by densely prominent or many small granules, which is supported to molecular phylogenetic analysis of Friesen et al. (2006).
Finally, we provided that seed testa sculpture is important character for the species and section level of Allium. Especially, the straight, Omega-, U- and S-type anticlinal walls can be used to distinguish taxa on the subgenus level.
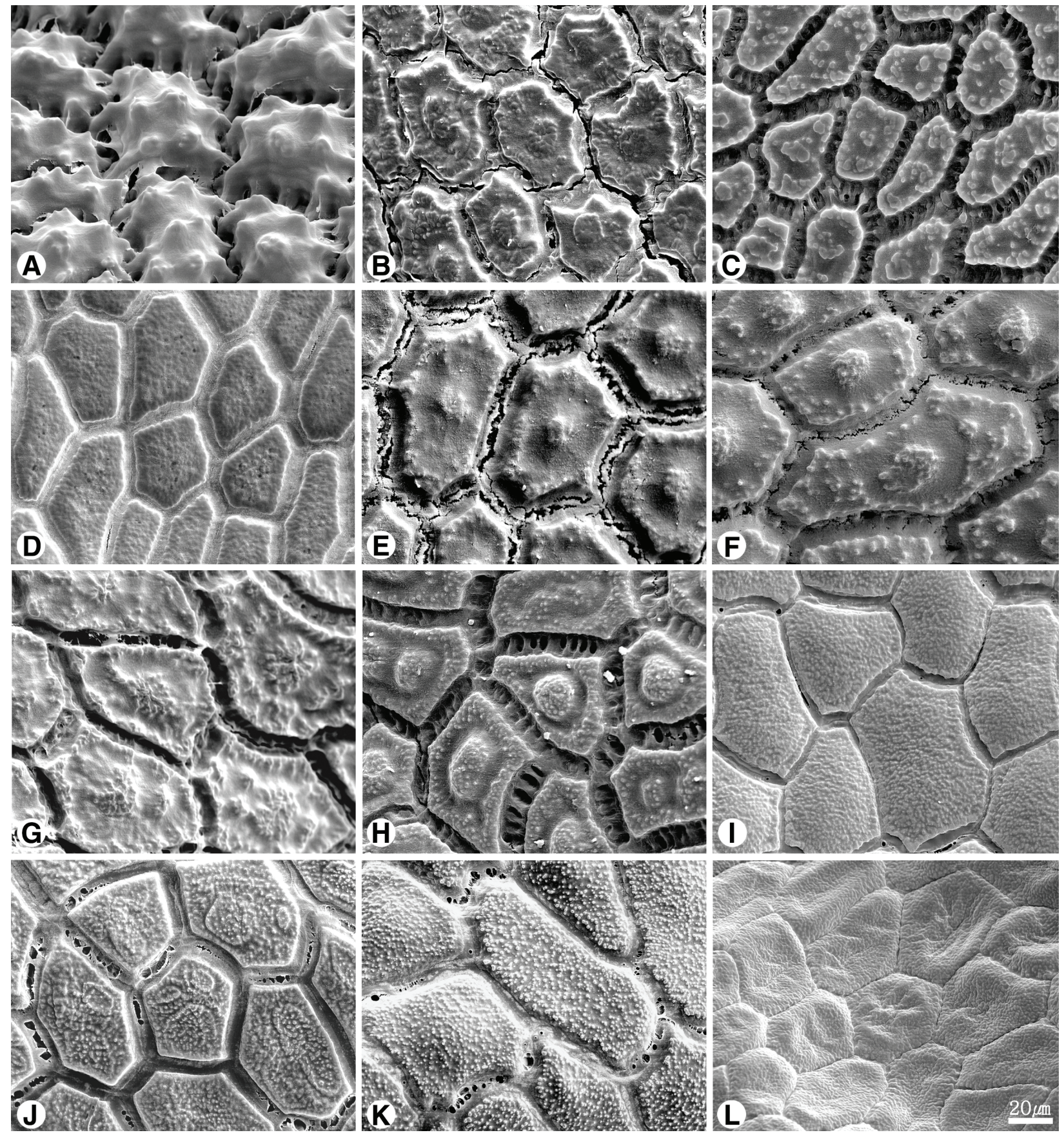

Fig. 2. Seed testa sculptures of Allium. A-D - subg. Polyprason: A - A. ochroleucum; B - A. suaveolens (sect. Daghestanica); C - A. zaprjagajevii (sect. Falcatifolia); D - A. stracheyi (sect. Oreiprason). E-L - subg. Reticulatobulbosa: E - A. oreoscordum; F - A. trachyscordum (sect. Campanulata); G - A. drobovii (sect. Nigrimontana); H - A. maackii (sect. Reticulatobulbosa); I - A. henryi; J - A. beesianum, $\mathrm{K}-A$. forrestii; $\mathrm{L}-$ A. sikkimense (sect. Sikkimensia) (Photo N. Friesen). 


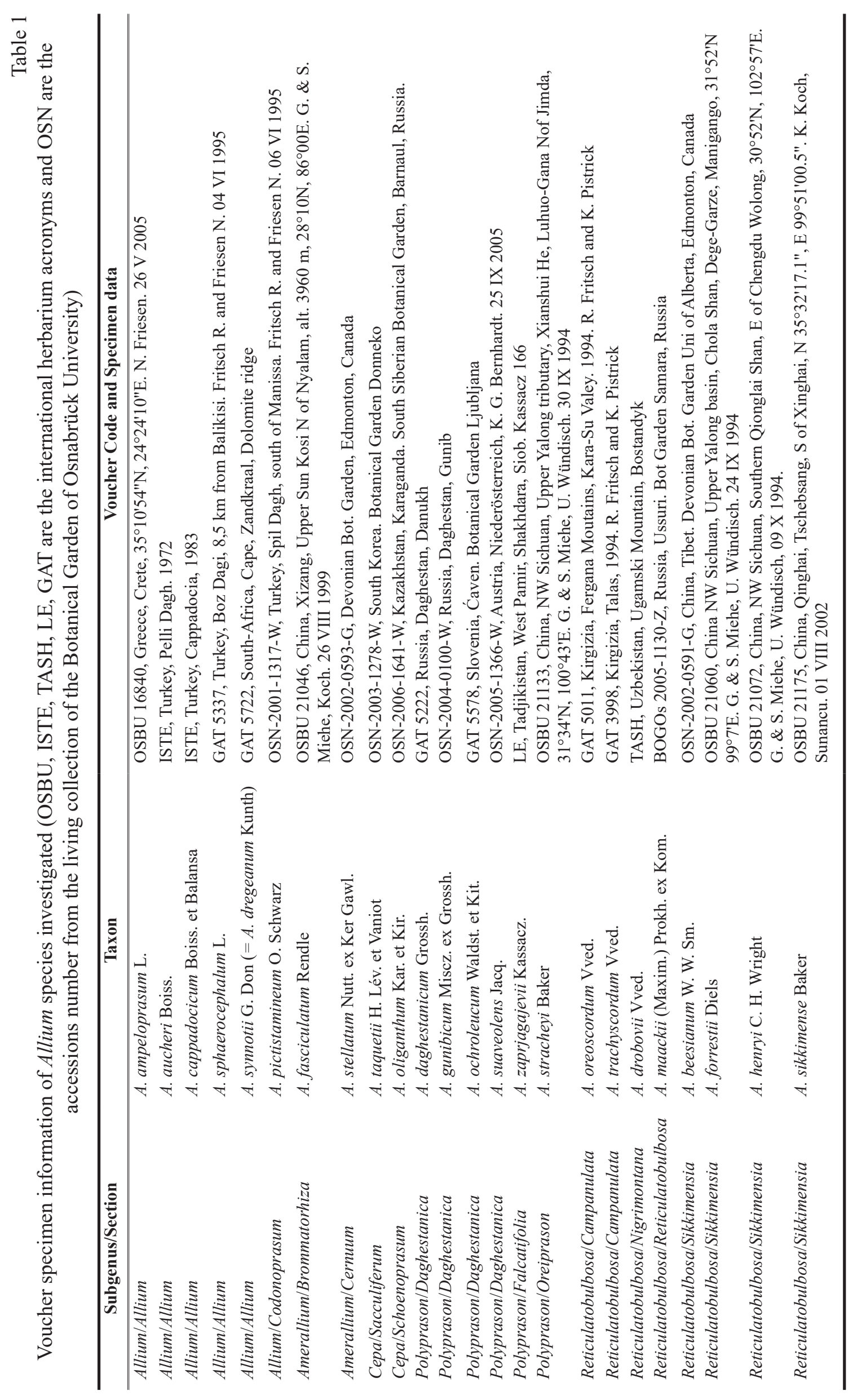


$\frac{N}{0}$

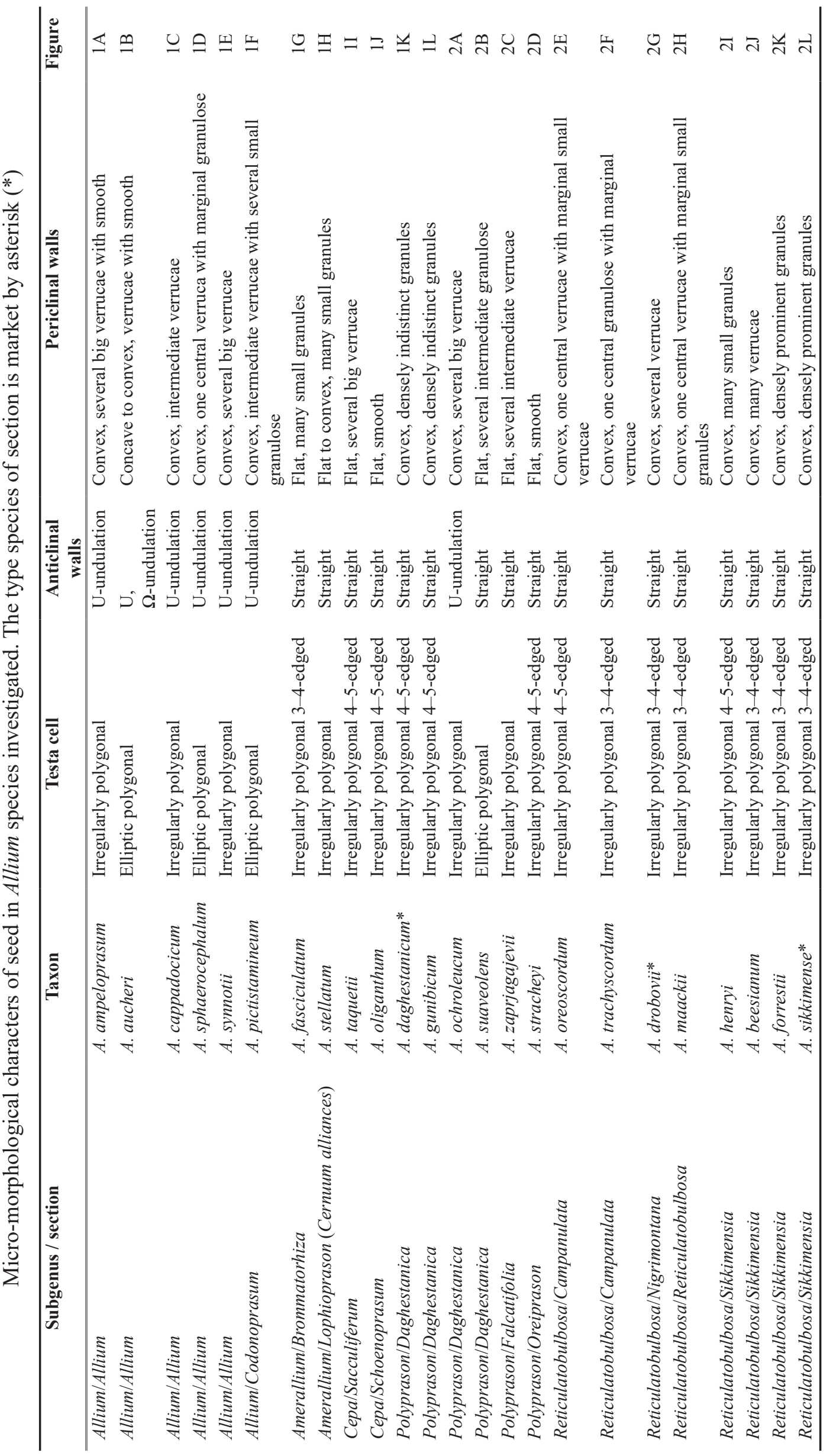




\section{REFERENCES}

Baasanmunkh S., Lee K. J., Jang J. E., Park M. S., Friesen N., Chung S., Choi H. J. 2020. Seed morphology of Allium L. (Amaryllidaceae) from central Asian countries and its taxonomic implications. Plants 9: 1239. DOI: 10.3390/plants9091239

Barthlott $\boldsymbol{W} .1981$. Epidermal and seed surface characters of plants: systematic applicability and some evolutionary aspects. Nordic Journal of Botany 1: 345-355. DOI: 10.1111/j.1756-1051.1981.tb00704.x

Bednorz L., Krzymińska A., Czarna A. 2011. Seed morphology and testa sculptures of some Allium L. species (Alliaceae). Acta Agrobotanica 64: 33-38. DOI: 10.5586/aa.2011.015

Celep F., Koyuncu M., Fritsch R. M., Kahraman A., Doğan M. 2012. Taxonomic importance of seed morphology in Allium (Amaryllidaceae). Systematic Botany 37: 893-912. DOI: 10.2307/23362707

Choi H. J., Cota-Sanchez J. H. 2010. A taxonomic revision of Allium (Alliaceae) in the Canadian prairie provinces. Botany 88: 787-809. DOI: 10.1139/B10-056

Choi H. J., Giussani L. M., Jang C. G., Oh B. U., Cota-Sanchez J. H. 2012. Systematics of disjunct northeastern Asian and northern North American Allium (Amaryllidaceae). Botany 90: 491-508. DOI: 10.1139/b2012-031

Denizi. G., Genç I., Sari D. 2015. Morphological and molecular data reveal a new species of Allium (Amaryllidaceae) from SW Anatolia, Turkey. Phytotaxa 212(4):283-292. DOI: 10.11646/phytotaxa.212.4.4

Duman H., Ekşi G., Özbek F. 2017. Two new species Allium L. sect. Allium (Amaryllidaceae) from Turkey. Plant Systematic Evolution 303: 1271-1291. DOI: 10.1007/s00606-017-1437-4

Friesen N., Fritsch R. M., Blattner F. R. 2006. Phylogeny and new intrageneric classification of Allium (Alliaceae) based on nuclear ribosomal DNA its sequences. Aliso 22: 372-395. DOI: 10.5642/aliso.20062201.31

Fritsch R. M., Friesen N. 2002. Evolution, domestication and taxonomy. In: Allium crop science: recent advances. Eds. H. D. Rabinowitch, L. Currah. Wallingford, Oxfordshire, UK: CABI Publishing. Pp. 5-30.

Govaerts R., Kington S., Friesen N., Fritsch R. M., Snijman D. A. Marcucci R., Silverstone-Sopkin P. A., Brullo S. 2005-2021. World checklist of Amaryllidaceae. Available at: http://apps.kew.org/wcsp/ (Accessed 21 January 2021).

Khasanov F. 2018. Taxonomical and ethnobotanical aspects of Allium species from Middle Asia with particular reference to subgenus Allium. In: The Allium Genomes, Compendium of Plant Genomes. Eds M. Shigyo, A. Khar, M. Abdelrahmam. Springer Nature Switzerland AG. Pp. 11-21. DOI: 10.1007/978-3-319-95825-5_2

Kruse J. 1984. Rasterelektronenmikroskopische Untersuchungen an Samen der Gattung Allium L. Die Kulturpflanze 32: 89-101.

Kruse J. 1986. Rasterelektronenmikroskopische Untersuchungen an Samen der Gattung Allium L. II. Die Kulturpflanze 34: 207-228.

Kruse J. 1988. Rasterelektronenmikroskopische Untersuchungen an Samen der Gattung Allium L. III. Die Kulturpflanze 36: 355-368.

Kruse J. 1994. Rasterelektronenmikroskopische Untersuchungen an Samen der Gattung Allium L. IV. Feddes Repertorium 105: 457-471. DOI: 10.1002/fedr.19941050711

Li Q. Q., Zhou S. D., He X. J., Yu Y., Zhang Y. C., Wei X. Q. 2010. Phylogeny and biogeography of Allium (Amaryllidaceae: Allieae) based on nuclear ribosomal internal transcribed spacer and chloroplast rps 16 sequences, focusing on the inclusion of species endemic to China. Annals of Botany 106: 709-733. DOI: 10.1093/aob/mcq177

Lin C. Y., Tan D. Y. 2017. Seed testa micromorphology of thirty-eight species of Allium (Amaryllidaceae) from central Asia, and its taxonomic implications. Nordic Journal of Botany 35: 189-200. DOI: 10.1111/njb.01259

Neshati F., Fritsch R. M. 2009. Seed characters and testa sculptures of some Iranian Allium L. species (Alliaceae). Feddes Repertorium 120: 322-332. DOI: 10.1002/fedr.200911112

Pastor J. 1981. Contribuciòn al estudio de las semillas de las especies de Allium de la Peninsula Ibèricae islas Baleares. Lagascalia 10: 207-216.

Veiskarami G., Khodayari H., Heubl G., Zarre S. 2018. Seed surface ultrastructure as an efficient tool for species delimitation in the Allium ampeloprasum L. alliance (Amaryllidaceae, Allioideae). Microscopy Research and Technique 81(11): 1275-1285. DOI: 10.1002/jemt.23134 